\title{
Penerapan budidaya bandeng semi intensif dengan metode modular di tambak Universitas Muslim Indonesia, Kali Bone Kabupaten Pangkep
}

\author{
Jayadi $^{1}$, Andi Asni ${ }^{2}$, Ilmiah ${ }^{3}$, Ida Rosada ${ }^{4}$ \\ 1,2,3Fakultas Perikanan dan Ilmu Kelautan, Universitas Muslim Indonesia \\ ${ }^{4}$ Fakultas Pertanian, Universitas Muslim Indonesia
}

\begin{abstract}
Innovation of semi-intensive milkfish cultivation and modular methods in the farming unit of the Indonesian Muslim University, Parreang Hamlet, Bontosunggu Village (Kalibone), Minasatene District, Pangkep Regency. The problem of demand for milkfish is the size of a lot of consumption, low production yields, traditional cultivation technology used, facilities and infrastructure are irrelevant, production management does not use good farming methods. The purpose of this activity is (1). applying the semi-intensive milkfish cultivation system technology innovation with a modular method, (2). Developing an economic culture, (3) creating new entrepreneurs of milkfish cultivation in ponds, (4) increasing milkfish production (4) stimulating the community to develop semiintensive milkfish cultivation with a modular method, (5) stimulating students to innovate and develop milkfish farming. The implementation method is a demonstration of milkfish farming in ponds ranging from pond preparation, natural food growth, seed stocking, artificial feeding and probiotics, handling water quality, pests, and diseases, and harvesting. The density of seeds stocked with a semi-intensive system was 10,000 heads / ha. Map the ponds used for shifting maintenance (modular method) of 3 ponds for 5 months. The results achieved are the production of milkfish with size of 5 milkfish / $\mathrm{kg}$ or $\pm 250 \mathrm{~g}$ as much as $423 \mathrm{~kg}$ with a net income of Rp.4,390,000. The maintenance cycle is carried out one cycle because of the dry season constraints from the planned 3 maintenance cycles.
\end{abstract}

Keywords: aquaculture, milkfish, innovation, modular, semi-intensive

\section{PENDAHULUAN}

Ikan bandeng (Chanos-chanos) atau "bale bolu" atau milkfish merupakan salah satu komoditas perikanan sebagai sumber makanan (protein) baik konsumsi lokal (pasar domestik) maupun untuk pasar ekspor serta digunakan sebagai umpang usaha penangkapan tuna dan cakalang (Faisyal, Rejeki dan Widowati, 2016). Penenuhan permintaan ikan bandeng umumnya dapat diperoleh dari hasil kegiatan budidaya di tambak, namun tingkat produksifitasnya masih relatif rendah, pertumbuhan lambat dan memerlukan waktu budidaya yang lama.

Rendahnya hasil produksi bandeng di tambak selain karena teknologi yang diterapkan masih tradisonal/ekstensif, juga karena belum menerapkan manajemen produksi dengan Cara Budidaya Ikan yang Baik (CBIB) dan berkelanjutan seperti manajemen penangan benih, manajemen kualitas air, manajemen pengendalian hama dan penyakit, manajamen pakan, dan sumberdaya manusia serta sarana dan prasana produksi.

Usaha untuk meningkatkan produksi tambak dapat dilakukan dengan menerapkan invovasi teknologi budidaya semi intensif (Sukmawati, Elfitasari, Rejeki, 2019) dengan sistem modular (DKP, 1996). Penerapan kegiatan inovasi tersebut telah dilaksanakan di Tambak Fakultas Perikanan dan Ilmu Keluatan (FPIK) Universitas Muslim Indonesia (UMI), di Dusun Parreang, Desa Bontosunggu (Kalibone), Kecamatan Minasatene, Kabupaten Pangkep (Gamba1) melalui Program Pengembangan Usaha Produk Intelektual Kampus (PPUPIK) berbasis akuakultur di tambak.

Tujuan kegiatan PPUPIK berbasis akuakultur di tambak adalah (1). Menerapkan budidaya tambak berbasis inovasi iptek sistem budidaya bandeng semi intesif dengan metode modular, (2). Mengembangkan budaya ekonomi di unit pertambakan FPIK UMI, (3) menciptakan 
wirausaha baru berbasis akuakultur terpadu di tambak, (4) meningkatkan produksi bandeng dari tambak FPIK UMI, (4) menstimulus masyarakat untuk mengembangkan budidaya bandeng sistem semi intensif dengan metode modular, (5) merangsang mahasiswa berinovasi dan berwirausaha budidaya bandeng. Manfaat kegiatan ini dapat menjadi solusi dalam meningkatkan produktifitas tambak.
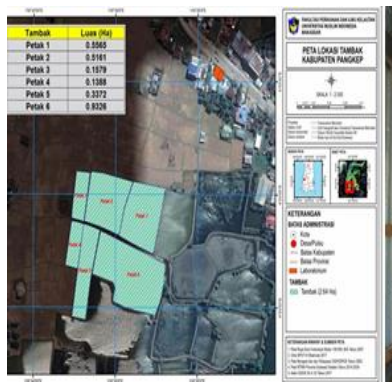

Gambar 1. Lokasi kegiatan PPUPIK berbasis akuakultur terpadu di tambak

\section{METODE PELAKSANAAN}

Pelaksanaan Pengembangan Usaha Produk Intelektual Kampus (PPUPIK) berbasis akuakultur di tambak terbagi beberapa kegiatan:

1. Pembenahan/pengadaan falilitas fasilitas tambak dengan membuat pintu utama tambak, memperbaiki pintu tambak, memperbaiki saluran tambak dan pematang tambak.

2. Menerapkan manajemen produksi budidaya bandeng secara semi intensif dengan metode modular.

3. Melakukan pencatatan keuangan meliputi biaya operasional produksi dan hasil produksi.

4. Penjualan produksi ke pasar.

5. Mengevaluasi kegiatan pelaksanaan PPUPIK.

\section{HASIL DAN PEMBAHASAN}

\section{A. Aspek Produksi}

Perbedaan sistim budidaya tradisional, semi intensif dan intensif ditandai dengan padat penebaran yang berbeda. Padat penebaran yang digunakan pada kegiatan ini yaitu 10.000 ekor/ ha/siklus, dilakukan dengan pengelolaan tanah, pengelolaan air, pengelolaan pemberian makanan dan penanganan penyakit. Pengelolaan tanah diawali dengan pengankatan lumpur, pengeringan, pengapuran, pemupukan, pemasukan air, pemberantasan hama, penumbuhan makanan alami (Gambar 2).

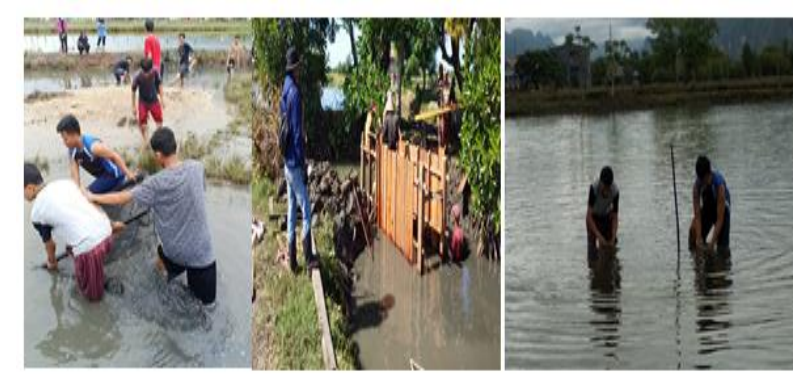

Gambar 2. Pengangkatan lumpur, perbaikan pintu utama tambak, pengukuran kualitas air

Pada kegiatan metode modular dilakukan pemeliharaan benih selama 1 bulan di kolam pendederan (petakan I), kemudian dipindahkan ke petakan II dan dipelihara 1 bulan (petak penggelondongan) dan selanjutnya dipindahkan ke petakan III (petak pembesaran) untuk pembesaran sampai ukuran konsumsi.dengan masa pemeliharaan 3 bulan.

Penebaran dilakukan setelah makanan alami tumbuh yang ditandai dengan tumbuhnya klekap. Pengelolaan kualitas air dilakukan dengan mengukur $\mathrm{pH}$, suhu, salinitas, amoniak yang dilakukan setiap minggu. Pemasukan dan pergantian air dilakukan berdasarkan pasang surut. Pengelolaan pemberian pakan buatan berprotein $40 \%$, dosis 10-15\% dari berat total populasi ikan yang hidup di tambak, dan frekwensi pemberian 2 kali sehari. Sampling pertumbuhan dilakukan setiap bulan. Penanganan penyakit dilakukan dengan memberikan probiotik setiap bulan sebanyak 5 liter. Probiotik berfungsi pula untuk merangsang pertumbuhan ikan di tambak dengan mencampur pada pakan buatan.

Produk teknologi yang diterapkan berupa produk ikan konsumsi setelah menerapkan teknologi budidaya semi intensi secara modular setelah masa pemeliharaan berumur 5 bulan. Ukuran ikan bandeng size 5 ekor/kg atau minimal $250 \mathrm{~g}$ untuk ukuran konsumsi dengan total produksi $423 \mathrm{~kg}$ per satu siklus. 


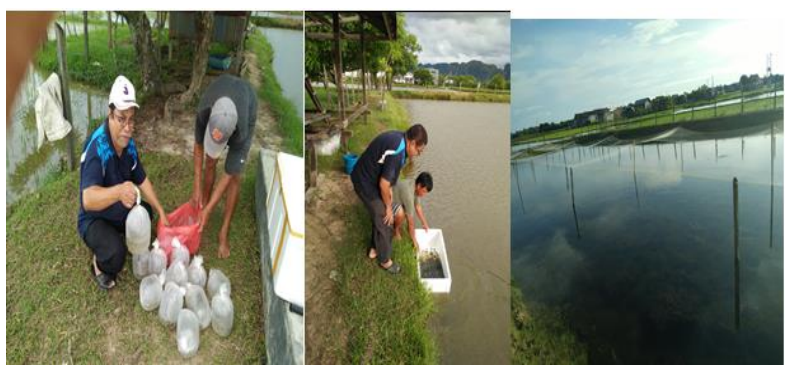

Gambar 3. Penebaran benih bandeng dan tambak pemeliharan

\section{B. Aspek Finansial}

Aspek finansial atau ekonomi untuk menggambarkan kinerja keuangan dari kegiatan pengembangan usaha produk intektual kampus berbasis akuakultur tambak. Analisa usaha menggambarkan keuntungan yang diperoleh dari kegiatan ini dalam satu siklus pemeliharaan, sedangkan analisis kreteria investasi menggambarkan kegiatan usaha untuk pengembangan dalam jangka panjang. Hasil penerimaa kotor per satu kali siklus yaitu $423 \mathrm{~kg}$ x Rp. $20.000=$ Rp. 8.640.000. Biaya operasional satu siklus Rp. 4.250.000. Pendapatan yang diterima selama satu siklus pemeliharaan sebesar Rp. 8.640.000 - Rp. $4.250 .000=$ Rp.4.390.000.

\section{Dampak Inovasi}

Dampak inovasi terhadap kegiatan ini terhadap mahasiswa yang ikut setelah dilakukan evaluasi menunjukkan bahwa pengetahuan dan keterampilan terjadi peningkatan sehingga merangsang mahasiswa menjadi wirausaha baru pada bidang akuakultur terpadu di tambak.

\section{Kendala/Hambatan}

Kedalam dalam pelaksanaa PPUPIK berbasis akuakutur terpadu di tambak yaitu kendala musim kemarau pada tahun 2019 sehingga hanya dilakukan satu siklus pemeliharaan, sedangkan rencana untuk program ini adalah 3 siklus pemeliharaan dalam setahun.

\section{KESIMPULAN}

Berdasarkan pelaksanaan kediatan Program Pengembangan Usaha Produk Intelektual Kampus (PPUPIK) berbasis akuakultur di tambak Dusun Parreang, Desa Bontosunggu (Kalibone), Kecamatan Minasatene, Kabupaten Pangkep dapat disimpulkan bahwa:

1. Aspek proses produksi yang dialakukan dengan menerapkan sistem intensif meliputi: pengelolaan tanah, pengelolaan air, pengelolaan pemberian makanan dan penanganan penyakit. Metode modular dilakukan model pemeliharan berpindah dari satu petakan kepetakan lainnya selama 5 bulan.

2. Produksi ikan konsumsi yang dihasilkan satu siklus pemeliharaan sebanyak $423 \mathrm{~kg}$ dengan nilai pendapatan sebesar Rp.4.390.000.

3. Inovasi teknologi ini dapat merangsang mahasiswa untuk melakukan wirausaha baru pada bidang akuakultur di tambak.

4. Menjadi percontohan model usaha budidaya bandeng semi intensif dengan sistim modular bagi masyarakat.

\section{DAFTAR PUSTAKA}

Faisyal, L., Rejeki, S., Widowati, L,L. (2016). Pengaruh padat penebaran terhadap pertumbuhan dan kelulusanhidup ikan bandeng (Chanos chanos) di Keramba Jaring Apung di Perairan Terabrasi Desa Kaliwlingi Kabupaten Brebes. Journal of Aquaculture Management and Technology, 5 (1) : 155-161.

Sukmawati, D,I., Elfitasari, T., Rejeki, S. (2018). Evaluasi Kelayakan Usaha Pembesaran Ikan Bandeng (Chanoschanos) Semi Intensif di Kecamatan Tayu Kabupaten Pati. Journal of Aquaculture Management and Technology, 7 (1) : 55- 63 . 